\section{Effects of Growing Media Containing Diatomaceous Earth on the Fungus Gnat Bradysia sp. nr. coprophila (Lintner) (Diptera: Sciaridae)}

\author{
Raymond A. Cloyd ${ }^{1}$ and Amy Dickinson ${ }^{2}$ \\ Department of Natural Resources and Environmental Sciences, University of \\ Illinois, Urbana, IL 61801
}

Additional index words. fungus gnats, soil amendments, integrated pest management, diatomaceous earth, growing media

\begin{abstract}
Fungus gnats (Bradysia spp.) are major insect pests in greenhouses. The adult stage is primarily a nuisance whereas the larval stage is directly responsible for plant injury by feeding on plant roots or tunneling into stems. Insecticides are used to deal with fungus gnat larvae in growing medium, although sometimes with limited success. This study evaluated the potential of using a soil amendment - diatomaceous earth (DE) incorporated into growing media-for controlling the fungus gnat Bradysia sp. nr. coprophila. Two experiments were conducted by testing a series of growing media containing various concentrations of diatomaceous earth, and several without diatomaceous earth. The effects of the growing media containing diatomaceous earth on both the 2 nd and 3 rd instars of fungus gnat larvae were determined by recording the number of adults captured on yellow sticky cards $(2.5 \times$ $2.5 \mathrm{~cm}$ ). Based on the results obtained from both experiments, the addition of DE to growing medium, at the concentrations tested, did not negatively affect or increase efficacy against both the 2nd and 3rd instars. This suggests that incorporating DE into commercially available growing medium may not be beneficial to greenhouse producers. However, further research is needed to assess whether differential larval susceptibility and moisture content influence the ability of DE to control soil-dwelling arthropods.
\end{abstract}

Fungus gnats (Bradysia spp.) (Diptera: Sciaridae) are common insect pests in greenhouse production systems (Dennis, 1978; Hamlen and Mead, 1979), particularly during propagation, which provides an ideal environment for population growth (Cloyd, 2000). The primary damaging stage is the larva, which feed on plant roots disrupting their ability to uptake water and nutrients (Hungerford, 1916; Leath and Newton, 1969; Wilkinson and Daugherty, 1970). In addition, larva can vector soilborne pathogens directly through feeding or creating wounds that allow entry for soilborne pathogens (Gardiner et al., 1990; Jarvis et al., 1993; Gillespie and Menzies, 1993).

Greenhouse producers traditionally use insecticides to control fungus gnat larvae (Hamlen and Mead, 1979; Lindquist et al., 1985). A conventional larvicide or insect growth regulator, applied as a drench, is generally successful in controlling the larval stage (Lindquist, 1994). However, due to regulatory restrictions on the use of insecticides (Sray, 1997) and the potential for resistance as a result of continual

Received for publication 15 Mar. 2005. Accepted for publication 27 Apr. 2005. The authors wish to thank Erick Caamano, Claudia Kuniyoshi, and Khalid Ibrahim for providing technical support. We also thank Richard P. Vetanovetz and Nancy Morgan of SunGro Horticulture, Inc., Bellevue, Wash., for providing funding for this research.

${ }^{1}$ Assistant Professor, To whom correspondence should be addressed; e-mail rcloyd@uiuc.edu.

${ }^{2}$ Research technician. Current address; National Soybean Research Laboratory, University of Illinois, Urbana. has been little, if any, research conducted to quantitatively demonstrate the use of growing media containing DE for control of soilborne insect pests such as fungus gnats, Bradysia spp. As a result, the purpose of this study was to determine if growing media containing different concentrations of DE negatively affect the fungus gnat Bradysia sp. nr. coprophila (Lintner).

\section{Materials and Methods}

This study, which consisted of two similar experiments, was conducted in the National Soybean Research Laboratory at the University of Illinois, Urbana-Champaign. Growing media were acquired from Sun Gro Horticulture (Marysville, Ohio) on 14 Feb. 2004. The growing media used in the study were Sunshine LC1 Mix, SB300 Universal, and Teufel Mix. Sunshine LC1 Mix was the base-growing medium in which DE was added to obtain the desired formulations. The components of this growing medium include peat moss, perlite, lime, a fertilizer charge, and a wetting agent. The growing media SB300 Universal and Teufel Mix, in addition to the components found in Sunshine LC1 Mix, also contain bark and vermiculite. Both these growing media did not contain DE. The DE formulations used in the study were Diafil (World Minerals, Inc., Santa Barbara, Calif.), Dicalite (Grefco, Lompoc, Calif.), and Fine Perlite (Seba Beach, Canada).

Fungus gnats. Fungus gnats used in this study were obtained from a laboratory colony of Bradysia sp. nr. coprophila (Lintner) maintained in moist soilless growing medium supplemented with shredded potato and oatmeal (Cloyd and Zaborski, 2004).

Experimental procedures. Fungus gnat larvae were reared to a known age using the following procedure. A standard glass petri dish $(100 \times 20-\mathrm{mm})$ was lined with moistened 90-mm Whatman No. 1 filter paper (Whatman, Maidstone, U.K.). The petri dish was filled with a mixture of sterilized Universal Mix (pine bark compost, Canadian sphagnum peat, horticultural vermiculite, perlite, and a wetting agent) and pureed potatoes at a ratio of 6 parts growing medium to 1-part potatoes. About $0.85 \mathrm{~g}$ ofrolled oatmeal was sprinkled onto the surface and then the growing medium was moistened with $35-\mathrm{mL}$ of deionized water using a 946-mL spray bottle. The petri dish was enclosed in a 739-mL Ziploc container with ventilation holes. About 30 to 40 fungus gnat adults (mixture of female and male) were collected from a laboratory colony into a 9-dram plastic vial (BioQuip Products, Rancho Dominguez, Calif.) secured with a cap, and then the vial (with the cap removed) was enclosed inside a Ziploc container, which was then placed into an environmental growth chamber (model CEL-36-10; Warren/Sherer Division of Kysor Industrial Corp., Marshall, Mich.) at a temperature of $24 \pm 3{ }^{\circ} \mathrm{C}$. The petri dish (with the cap removed) remained in the chamber for $48 \mathrm{~h}$ to allow the female to mate, and then lay eggs. After $48 \mathrm{~h}$, the petri dish was removed from the Ziploc container and $1.0 \mathrm{~mL}$ of deionized water was applied to the growing 
medium surface. A glass lid was placed on the petri dish, which was then returned to the growth chamber. The petri dish was checked daily and $0.5 \mathrm{~mL}$ of deionized water was applied to the surface to prevent the growing medium from drying out. Under the environmental conditions of the growth chamber, fungus gnat larvae were 2 nd instars after 7 to $8 \mathrm{~d}$, and 3 rd instars after 10 to $11 \mathrm{~d}$ using size to differentiate between the larval instars (Zaborski and Cloyd, 2004).

The petri dish surface was carefully evaluated using a dissecting microscope, to assess the fungus gnat larval population. A small sample of growing medium ( 0.85 to $1.4 \mathrm{~g}$ ) containing larvae was removed, using a laboratory spoon, from the original petri dish and placed into another glass petri dish $(100 \times 20 \mathrm{~mm})$. The sample was carefully washed with deionized water and then the petri dish was filled with water. The petri dish was examined using a dissecting microscope and any floating larvae were collected with a micropipette. The larvae were placed into a small glass petri dish $(60$ $\times 15 \mathrm{~mm}$ ) and covered with deionized water. Larvae remained in the water for up to 30 min or until they were applied to the samples. Before inoculating the samples, 2nd and 3rd instars were counted again using a dissecting microscope to double check counts.

The growing media tested and used for the samples were placed into a dishpan and moistened with deionized water. Each growing medium sample was thoroughly mixed $48 \mathrm{~h}$ before adding fungus gnat larvae. The sample consisted of $300 \mathrm{~mL}$ of growing medium. The growing medium was measured into a $600-\mathrm{mL}$ glass beaker and compressed (to remove air space) to the $300-\mathrm{mL}$ mark. In total, $1.4 \mathrm{~g}$ of rolled oatmeal was applied to the sample and $100 \mathrm{~mL}$ of deionized water was added, except for the Teufel mix in which $85 \mathrm{~mL}$ of deionized water was added. The sample was mixed and then placed into a $473-\mathrm{mL}$ polypropylene deli container (Fabri-Kal Corp.; Kalamazoo, Mich.) and compressed again. Ten to twelve small holes (about $2 \mathrm{~mm}$ ) were punctured on the bottom using a dissecting probe. The samples were placed into the growth chamber for $48 \mathrm{~h}$, which allowed time for fungal growth, before inoculating with larvae. Both 2nd and 3rd instars were used. Seven-day-old 2nd instars and 11-d-old 3rd instars were applied to the growing medium samples. Twenty larvae ( $2 \mathrm{nd}$ or 3rd instar depending on the sample) from the petri dish (described above) were poured onto each sample and then the petri dish was rinsed with $50 \mathrm{~mL}$ of deionized water to ensure that all larvae had been placed onto the growing medium. There were seven replications per sample $(\mathrm{n}=12)$ for each larval instar $(\mathrm{n}=$ 2) for a total of 168 samples. The inoculated samples were then returned to the growth chamber. Each deli container was placed onto the lid of a petri dish $(100 \times 20 \mathrm{~mm})$ containing water, which could be taken up through the holes on the bottom of the deli containers. This prevented the growing medium from drying out. Every week, $50 \mathrm{~mL}$ of deionized water was added to the petri dish lids to maintain a consistent moisture level. In addition, $4.0 \mathrm{~mL}$ of deionized water was applied to the surface of the growing medium every week. Each deli container had a yellow sticky card $(2.5 \times$ $2.5 \mathrm{~cm}$ ) attached to the underside of the lid to capture adults that emerged from the growing medium. Both experiments were set-up as a completely randomized design.

Data for the number of adults captured on the yellow sticky cards as well as the number of adults that were flying around within the deli container for each experiment were analyzed using a one-way analysis of variance (ANOVA) (SAS Institute, 2001) with growing medium as the main effect. The data were normally distributed for the adult counts. The means for the number of fungus gnat adults recovered from both 2nd and 3rd instar samples for the different growing media were separated using a Fisher's protected least significant difference (LSD) test at $P \leq 0.05$.

Gravimetric moisture content of each growing medium sample was determined both before and after conducting the experiments based on five samples placed in petri dishes $(100 \times 20 \mathrm{~mm})$ and then drying $100 \mathrm{~mL}$ of growing medium to a constant mass in a forced-air drying oven at $60 \pm 1{ }^{\circ} \mathrm{C}$. This established the mean moisture content for each growing medium expressed as a percentage. The formula used to obtain the percent moisture content was

$\frac{(\mathrm{B}-\mathrm{A})-(\mathrm{C}-\mathrm{A})}{\mathrm{B}-\mathrm{A}} \times 100=\%$ moisture content where $\mathrm{A}=$ weight $(\mathrm{g})$ of petri dish, $\mathrm{B}=$ initial weight $(\mathrm{g})$ (petri dish + moist growing medium), and $\mathrm{C}=$ final weight (g) (petri dish + dry growing medium).

\section{Results}

Experiment 1. Percent moisture content before the experiment ranged from $24 \%$ to $66 \%$ (Table 1). Percent moisture content after the experiment ranged from $49 \%$ to $82 \%$ for the growing media inoculated with 2 nd instars and $53 \%$ to $76 \%$ for growing media inoculated with 3rd instars. The moisture content for the SB300 Universal was always much lower than the other growing media $(24 \%, 49 \%$, and $53 \%$, respectively)(Table 1). Growing medium effect was significant for the number of fungus gnat adults recovered from samples inoculated with 2nd instar larvae $(F=2.57 ; \mathrm{df}=11,83 ; P=$ 0.0083 ) with the growing medium containing the highest concentration of DE in the Dicalite formulation $\left(30 \mathrm{lbDE} / \mathrm{yard}^{3}\right)$ having the lowest adult emergence $(5.4 \pm 0.5$; mean \pm SE) (Table 2 ). This growing medium was significantly different from all the other growing media tested with the exception of the Sunshine LC1 Mix $(6.0 \pm 0.8 ;$ mean $\pm \mathrm{SE}), \mathrm{SB} 300$ Universal $(8.4 \pm$ 1.6 ; mean $\pm \mathrm{SE})$, and the lowest concentration ofDE in the formulation Diafil $\left(10 \mathrm{lb} \mathrm{DE} / \mathrm{yard}^{3}\right)$ $(6.5 \pm 1.4$; mean $\pm \mathrm{SE})$. Growing medium was not significant for the number of fungus gnat adults recovered from samples inoculated with

Table 1. Percent moisture content of final material (growing media) containing diatomaceous earth (DE) tested before and after the first experiment.

\begin{tabular}{|c|c|c|c|c|c|}
\hline \multirow[b]{3}{*}{ Formulation name } & \multirow{3}{*}{ 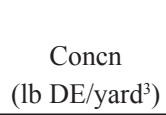 } & \multirow[b]{3}{*}{$\mathrm{n}$} & \multicolumn{3}{|c|}{ Moisture content $(\%)$} \\
\hline & & & \multirow{2}{*}{$\begin{array}{c}\text { Before } \\
\text { 2nd and 3rd Instar }\end{array}$} & \multicolumn{2}{|c|}{ After } \\
\hline & & & & 2nd Instar & 3rd Instar \\
\hline Diafil & 10 & 5 & 53 & 78 & 75 \\
\hline Diafil & 20 & 5 & 52 & 76 & 71 \\
\hline Diafil & 30 & 5 & 53 & 76 & 68 \\
\hline Dicalite & 10 & 5 & 53 & 76 & 69 \\
\hline Dicalite & 20 & 5 & 52 & 80 & 71 \\
\hline Dicalite & 30 & 5 & 53 & 74 & 65 \\
\hline Fine Perlite & 10 & 5 & 61 & 78 & 75 \\
\hline Fine Perlite & 20 & 5 & 56 & 77 & 73 \\
\hline Fine Perlite & 30 & 5 & 53 & 76 & 65 \\
\hline Teufel Mix & --- & 5 & 50 & 62 & 57 \\
\hline Sunshine LC1 Mix & -- & 5 & 66 & 82 & 76 \\
\hline SB300 Universal & --- & 5 & 24 & 49 & 53 \\
\hline Mean $( \pm$ SE $)$ & & & $52.1 \pm 2.9$ & $73.6 \pm 2.6$ & $68.1 \pm 2.1$ \\
\hline Range & & & 24-66 & $49-82$ & $53-76$ \\
\hline
\end{tabular}

Table 2. Mean adult fungus gnat (Bradysia sp. nr. coprophila) emergence based on yellow sticky card (2.5 $\times 2.5 \mathrm{~cm}$ ) counts from growing medium samples initially inoculated with 2 nd and 3rd instar fungus gnat larvae for final material (growing media) containing diatomaceous earth (DE) and other growing media tested for the first experiment. There were about 20 fungus gnat larvae used per replication.

\begin{tabular}{lcccc}
\hline Formulation name & $\mathrm{n}$ & $\begin{array}{c}\text { Concn } \\
(\text { lb DE/yard })\end{array}$ & $\begin{array}{c}\text { 2nd Instar } \\
(\text { mean } \pm \text { SE) }\end{array}$ & $\begin{array}{c}\text { 3rd Instar } \\
(\mathrm{mean} \pm \mathrm{SE})\end{array}$ \\
\hline Diafil & 7 & 10 & $6.5 \pm 1.4 \mathrm{bcd}^{\mathrm{z}}$ & $11.5 \pm 1.4 \mathrm{a}$ \\
Diafil & 7 & 20 & $10.0 \pm 1.2 \mathrm{a}$ & $10.7 \pm 1.7 \mathrm{a}$ \\
Diafil & 7 & 30 & $9.0 \pm 1.0 \mathrm{abc}$ & $11.3 \pm 0.8 \mathrm{a}$ \\
Dicalite & 7 & 10 & $10.8 \pm 0.8 \mathrm{a}$ & $11.6 \pm 1.2 \mathrm{a}$ \\
Dicalite & 7 & 20 & $10.0 \pm 0.5 \mathrm{a}$ & $12.6 \pm 0.8 \mathrm{a}$ \\
Dicalite & 7 & 30 & $5.4 \pm 0.5 \mathrm{~d}$ & $8.4 \pm 1.0 \mathrm{a}$ \\
Fine Perlite & 7 & 10 & $9.5 \pm 0.8 \mathrm{ab}$ & $12.3 \pm 1.2 \mathrm{a}$ \\
Fine Perlite & 7 & 20 & $9.4 \pm 1.6 \mathrm{ab}$ & $11.1 \pm 0.4 \mathrm{a}$ \\
Fine Perlite & 7 & 30 & $9.4 \pm 0.6 \mathrm{ab}$ & $12.6 \pm 1.1 \mathrm{a}$ \\
Teufel Mix & 7 & --- & $9.7 \pm 0.9 \mathrm{a}$ & $7.8 \pm 1.1 \mathrm{a}$ \\
Sunshine LC1 Mix & 7 & --- & $6.0 \pm 0.8 \mathrm{~cd}$ & $11.4 \pm 0.9 \mathrm{a}$ \\
SB300 Universal & 7 & --- & $8.4 \pm 1.6 \mathrm{abcd}$ & $11.3 \pm 1.3 \mathrm{a}$ \\
\hline
\end{tabular}

zMeans not followed by a common letter are significantly different $(P=0.05)$ as determined by Fisher's protected least significant difference (LSD) test. 
3rd instar larvae $(F=1.63 ; \mathrm{df}=11,83 ; P=$ 0.109) (Table 2).

Experiment 2. Percent moisture content before the experiment ranged from $43 \%$ to $66 \%$ (Table 3). After the experiment, percent moisture content ranged from $71 \%$ to $85 \%$ instars and $75 \%$ to $85 \%$ for growing media inoculated with 3 rd instars. In contrast with the first experiment, the moisture content for the SB300 Universal was only lower (43\%) before the experiment was conducted (Table 3). Growing medium was not significant for the number of fungus gnat adults recovered from samples inoculated with 2 nd instars $(F=$ 1.69 ; $\mathrm{df}=11,83 ; P=0.095)$, however, growing medium was significant for the number of fungus gnat adults recovered from samples inoculated with $3 \mathrm{rd}$ instars $(F=3.36$; $\mathrm{df}=11$, $83 ; P=0.001)$ with all the growing media having lower adult emergence values than SB300 Universal (Table 4).

\section{Discussion}

The insecticidal activity ofDE may depend on a number of factors such as uniform particle size $(\geq 10 \mu \mathrm{m})$, percent of particles with a diameter $<12 \mu \mathrm{m}$, distribution of diatom particles, and oil adsorption capacity (Korunic 1998). However, insect sensitivity to DE may be related more to anatomy and physiology. For example, insects with a large surface area for the growing media inoculated with 2 nd

in relation to volume of body, rough or hairy body surface, and thin cuticle thickness are more sensitive to DE, which may be related to larval instar stage or adult (Carlson and Ball, 1962). In fact, there may be a wide variation in insect susceptibility to DE (Rigaux et al., 2001).

Any variation in larval susceptibility such as the 2 nd and 3rd instars of fungus gnat to DE may be due to reduced movement, cuticle thickness (Korunic, 1998), and where fungus gnats pupate (Zaborski and Cloyd, unpublished data). Insects that are active are more likely to be damaged than sedentary insects (Fields and Korunic, 1996). Minimal movement by the larval stage in the growing medium could result in less DE, depending on concentration, coming in contact with the insect's body (cuticle) as it migrates through the growing medium profile (Rigaux et al., 2001). Diatomaceous earth will affect insects as long as there is a sufficient concentration to ensure that insects come in contact with enough diatom particles (Korunic 1998). Any variation in the concentration of DE may impact efficacy as insects are exposed to fewer diatom particles as less $\mathrm{DE}$ is incorporated into the growing medium. However, it has not been shown that one instar of fungus gnat is more active than the other or there are differences in larval stage susceptibility. In the first experiment, growing media (those with and without DE) appeared to have a numerically greater negative effect, based on

Table 3. Percent moisture content of growing media (formulation name) containing diatomaceous earth (DE) tested before and after the second experiment.

\begin{tabular}{|c|c|c|c|c|c|}
\hline \multirow[b]{3}{*}{ Formulation name } & \multirow{3}{*}{$\begin{array}{c}\text { Concn } \\
(\text { lb DE/yard })\end{array}$} & \multirow[b]{3}{*}{$\mathrm{n}$} & \multicolumn{3}{|c|}{ Moisture content (\%) } \\
\hline & & & \multirow{2}{*}{$\frac{\text { Before }}{\text { 2nd and 3rd Instar }}$} & \multicolumn{2}{|c|}{ After } \\
\hline & & & & 2nd Instar & 3rd Instar \\
\hline$\overline{\text { Diafil }}$ & 10 & 5 & 52 & 84 & 83 \\
\hline Diafil & 20 & 5 & 50 & 83 & 82 \\
\hline Diafil & 30 & 5 & 43 & 82 & 81 \\
\hline Dicalite & 10 & 5 & 50 & 84 & 82 \\
\hline Dicalite & 20 & 5 & 50 & 78 & 82 \\
\hline Dicalite & 30 & 5 & 50 & 82 & 81 \\
\hline Fine Perlite & 10 & 5 & 58 & 85 & 84 \\
\hline Fine Perlite & 20 & 5 & 55 & 84 & 83 \\
\hline Fine Perlite & 30 & 5 & 48 & 84 & 81 \\
\hline Teufel Mix & --- & 5 & 50 & 71 & 65 \\
\hline Sunshine LC1 Mix & --- & 5 & 66 & 85 & 85 \\
\hline SB300 Universal & --- & 5 & 43 & 76 & 75 \\
\hline Mean $( \pm \mathrm{SE})$ & & & $51.2 \pm 1.8$ & $81.5 \pm 1.2$ & $80.3 \pm 1.6$ \\
\hline Range & & & $43-66$ & $71-85$ & $75-85$ \\
\hline
\end{tabular}

Table 4. Mean adult fungus gnat (Bradysia sp. nr. coprophila) emergence based on yellow sticky card (2.5 $\times 2.5 \mathrm{~cm}$ ) counts from growing medium samples initially inoculated with 2 nd and 3rd instar fungus gnat larvae for growing media containing diatomaceous earth (DE) and other growing media tested for the second experiment. There were about 20 fungus gnat larvae used per replication.

\begin{tabular}{lcccc}
\hline Formulation name & $\mathrm{n}$ & $\begin{array}{c}\text { Concn } \\
\left(\mathrm{lb} \mathrm{DE} / \mathrm{yard}^{3}\right)\end{array}$ & $\begin{array}{c}\text { 2nd Instar } \\
(\text { mean } \pm \mathrm{SE})\end{array}$ & $\begin{array}{c}\text { 3rd Instar } \\
(\text { mean } \pm \mathrm{SE})\end{array}$ \\
\hline Diafil & 7 & 10 & $7.5 \pm 1.2 \mathrm{a}^{\mathrm{z}}$ & $4.3 \pm 0.9 \mathrm{bc}$ \\
Diafil & 7 & 20 & $8.4 \pm 2.1 \mathrm{a}$ & $4.1 \pm 0.5 \mathrm{bc}$ \\
Diafil & 7 & 30 & $10.4 \pm 1.7 \mathrm{a}$ & $3.8 \pm 0.7 \mathrm{bc}$ \\
Dicalite & 7 & 10 & $8.7 \pm 1.1 \mathrm{a}$ & $3.7 \pm 0.9 \mathrm{bc}$ \\
Dicalite & 7 & 20 & $9.0 \pm 1.4 \mathrm{a}$ & $2.0 \pm 0.4 \mathrm{c}$ \\
Dicalite & 7 & 30 & $5.1 \pm 0.8 \mathrm{a}$ & $3.3 \pm 0.9 \mathrm{bc}$ \\
Fine Perlite & 7 & 10 & $5.7 \pm 0.8 \mathrm{a}$ & $5.0 \pm 1.5 \mathrm{~b}$ \\
Fine Perlite & 7 & 30 & $7.2 \pm 1.1 \mathrm{a}$ & $3.7 \pm 0.8 \mathrm{bc}$ \\
Fine Perlite & 7 & --- & $10.3 \pm 1.4 \mathrm{a}$ & $3.3 \pm 1.2 \mathrm{bc}$ \\
Teufel Mix & 7 & --- & $8.1 \pm 1.5 \mathrm{a}$ & $5.8 \pm 1.0 \mathrm{~b}$ \\
Sunshine LC1 Mix & 7 & --- & $9.0 \pm 1.7 \mathrm{a}$ & $3.7 \pm 0.7 \mathrm{bc}$ \\
SB300 Universal & 7 & & $9.3 \pm 1.1 \mathrm{a}$ \\
\hline
\end{tabular}

${ }^{2}$ Means not followed by a common letter are significantly different $(P=0.05)$ as determined by Fisher's protected least significant difference (LSD) test. adult emergence, for 2 nd instars compared to 3rd instars as more adults (on average) tended to emerge from growing media inoculated with 3 rd instars than 2 nd instars (Table 2). It is possible this is due to the $3 \mathrm{rd}$ instars having a thicker cuticle, which could decrease their susceptibility to injury from either DE or other growing medium particulates, resulting in less mortality. The one exception to this hypothesis is the Teufel mix in which fewer adults emerged in the 3rd instar inoculated growing medium than the 2nd instar inoculated growing medium. Additionally, the location of fungus gnat larvae in the growing medium profile may influence the efficacy of DE. Preliminary studies have demonstrated that fungus gnat larvae and pupae are distributed throughout the growing medium profile(Zaborski and Cloyd, unpublished data), which may influence susceptibility to growing media containing lower concentrations of DE. Also, fungus gnat larvae feeding within plant roots or stems may escape any detrimental affects from growing media containing DE (Hungerford, 1916). It has been suggested that fungus gnat adults may be negatively affected by growing medium containing $\mathrm{DE}$ as they emerge from pupae (Quarles, 1992) resulting in increased mortality and/or reduced fitness and reproduction. The reason why there were no significant differences among the growing media for the 3 rd instars was due to the low adult emergence from all the growing media (Table 4).

In general, the percent moisture content of the growing media used before each experiment were similar based on the mean $( \pm \mathrm{SE})$ moisture content $(52.1 \pm 2.9$ for the first experiment and $51.2 \pm 1.8$ for the second experiment) and range of moisture contents $(24 \%$ to $66 \%$ for the first experiment and $43 \%$ to $66 \%$ for the second experiment) (Tables 1 and 3 ) with the exception of SB300 Universal (24\% vs. $43 \%$, respectively). The variable moisture content of the SB300 Universal may be due to the physical characteristics or composition of the components.

The one noticeable difference in the data, based on recovery rate, was the lower number of fungus gnat adults obtained from 3rd instars in the second experiment compared to the first experiment (Tables 2 and 4). This may be a response to the different percent moisture contents between both experiments. Measurements of percent moisture content did vary after completion of the experiments in regards to both instars with percent moisture contents (mean \pm SE) for the 2 nd and 3 rd instars in experiment one lower $(73.6 \pm 2.6$ and 68.1 \pm 2.1 , respectively) than those for the 2 nd and 3 rd instars in the second experiment $(81.5 \pm 1.2$ and $80.3 \pm 1.6$, respectively) (Tables 1 and 3 ). These differences in percent moisture content may account for the variability in recovery rates experienced in both experiments for the 3 rd instars. Although the range of fungus gnat adult emergence was similar for 2 nd instars in both experiments (5.4 to 10.8 and 5.1 to 10.4 , respectively), the relative number of adults that emerged was lower in the second experiment compared to the first experiment (Tables 2 and 4). Again, this may be due to 
the percent moisture content. Preliminary data have shown that excessive moisture levels may be harmful to fungus gnat larvae thus affecting adult emergence (Cloyd and Dickinson, unpublished data). Although not directly evaluated in this study, moisture content may also have influenced the efficacy of DE to control fungus gnats (Korunic, 1998) as DE has been shown to less effective under moist conditions (Maceljski and Korunic, 1971).

Based on the results from both experiments, the incorporation of DE into growing medium had no influence on the 2 nd and $3^{\text {rd }}$ instars of the fungus gnat, $B$. sp. nr. coprophila. This study has demonstrated that the use of DE as an amendment incorporated into growing media, at the concentrations tested, does not negatively affect fungus gnat larvae, which suggests that incorporating $\mathrm{DE}$ into growing medium may not be beneficial to greenhouse producers. However, further studies are needed to access whether there is differential larval susceptibility (first instar vs. later instars) to DE and if moisture content influences the efficacy of DE.

\section{Literature Cited}

Arthur, F.H. 2000a. Toxicity of diatomaceous earth to red flour beetles and confused flourbeetles (Coleoptera: Tenebrionidae): Effects of temperature and relative humidity. J.Econ. Entomol. 93:526-532.

Arthur, F.H.2000b. Impact of food source on survival of red flour beetles and confused flourbeetles (Coleoptera: Tenebrionidae) exposed to diatomaceous earth. J. Econ. Entomol. 93:1347-1356.

Carlson, S.D. and H.J. Ball. 1962. Mode of action and insecticidal value of a diatomaceous earth as a grain protectant. J. Econ. Entomol. 55:964-970.

Cloyd, R.A. and E.R. Zaborski. 2004. Fungus gnats, Bradysia spp. (Diptera: Sciaridae), and other arthropods in commercial bagged soilless growing media and rooted plant plugs. J. Econ. Entomol. 97:503-510.
Cloyd, R.A. 2000. Fungus gnat and shore fly management strategies: Panel discussion, p. 57-59. In: Proceedings for the 16th Conference on Insect and Disease Management on Ornamentals. Soc. Amer. Florists, Alexandria, Va.

Dennis, D.J. 1978. Observations of fungus gnat damage to glasshouse curcubits. N.Z. J. Expt. Agr. 6:83-84.

Ebeling, W. 1971. Sorptive dusts for pest control. Annu. Rev. Entomol. 16:123-158.

Fields, P. and Z. Korunic. 1996. Diatoms industrial use: Diatomaceous earth as an insecticide. http://hjs.geol.uib.no/diatoms/industry/de-web. shtml.

Gardiner, R.B., W.R. Jarvis, and J.L. Shipp. 1990. Ingestion of Pythium spp. by larvae of the fungus gnat Bradysia impatiens (Diptera: Sciaridae) Ann. Appl. Biol. 116:205-212.

Gillespie, D.R., and J.G. Menzies. 1993. Fungus gnats vector Fusarium oxysporum f. sp. radicislycopersici. Ann. Appl. Biol. 123:539-544.

Hamlen, R.A. and F.W. Mead. 1979. Fungus gnat larval control in greenhouse plant production. J. Econ. Entomol. 72:269-271.

Hungerford, H.B. 1916. Sciara maggots injurious to potted plants. J. Econ. Entomol. 9:538-549.

Jarvis, W.R., J.L. Shipp, and R.B. Gardiner. 1993. Transmission of Pythium aphanidermatum to greenhouse cucumber by the fungus gnat Bradysia impatiens (Diptera: Sciaridae). Ann. Appl. Biol. 122:23-29.

Korunic, Z. 1998. Diatomaceous earths, a group of natural insecticides. J. Stored Prod. Res. 34:87-97.

Korunic, Z., P.G. Fields, N.D.G. White, A. MacKay, and B. Timlick. 1996. The effectiveness of diatomaceous earth against stored-grain insects pests in farm storages, p. 557. In: Proceedings XX International Congress of Entomology, Firenza, Italy.

Lacey, L.A. and M.S. Mulla. 1977. Evaluation of Bacillus thuringiensis as a biocide of blackfly larvae (Diptera: Simuliidae). J. Invert. Pathol. 30:46-49.

Leath, K.T. and R.C. Newton. 1969. Interaction of a fungus gnat, Bradysia sp. (Sciaridae) with Fusarium spp. on alfalfa and red clover. Phytopathology 59:257-258.
Le Patourel, G.N.J., M. Shawir, and F.I. Moustafa. 1989. Accumulation of mineral dusts from wheat by Sitophilus oryzae (L.) (Coleoptera: Curculionidae). J. Stored Prod. Res. 25:65-72.

Lindquist, R.K. 1994. Integrated management of fungus gnats and shore flies, p. 58-67. In: K. Robb (ed.). Proceedings for the 10th Conference on Insect and Disease Management on Ornamentals, 19-21 Feb. 1994, Dallas, Texas. Soc. Amer. Florists, Alexandria, Va.

Lindquist, R.K., W.R. Faber, and M.L. Casey. 1985. Effect of various soilless root media and insecticides on fungus gnats. HortScience 20:358-360.

Maceljski, M. and Z. Korunic. 1971. Trials of inert dusts in water suspension for controlling storedproduct pests. Zastita Bilja (Plant Protection) Belgrade 22:119-128.

Mewis, I. and C. Ulrichs. 2001. Action of amorphous diatomaceous earth against differentstages of the stored product pests Tribolium confusum, Tenebrio molitor, Sitophilus granarius and Plodia interpunctella. J. Stored Prod. Res. 37:153-164.

Nedstam, B. and M. Burman. 1990. The use of nematodes against sciarids in Swedish greenhouses. SROP/WPRS Bull. XIII/5:147-148.

Quarles, W. and P. S. Winn. 1996. Diatomaceous earth and stored product pests. IPM Practitioner 18:1-10.

Quarles, W. 1992. Diatomaceous earth for pest control. IPM Practitioner 14(5/6):1-11.

Rigaux, M., E. Haubruge, and P.G. Fields. 2001. Mechanisms for tolerance to diatomaceous earth between strains of Tribolium castaneum. Entomol. Expt. Appl. 101:33-39.

SAS Institute, Inc. 2001. SAS/STAT users guide. v. 8.0. SAS Institute, Inc., Cary, N.C.

Sray, A. 1997. FQPA in the greenhouse. Greenhouse Grower 15:70-71.

Wilkinson, J.D. and D.M. Daugherty. 1970. The biology and immature stages of Bradysia impatiens (Diptera: Sciaridae). Ann. Entomol. Soc. Amer. 63:656-660.

Zaborski, E.R. and R.A. Cloyd. 2004. Method for quantitative sampling of fungus gnat larvae in soilless growing media. J. Econ. Entomol. 97:678-686. 